
\title{
28 Research Square \\ A Decade of National Green Tribunal of India: Judgement Analysis and Observations
}

aprajita singh ( $\square$ singhaprajita33@gmail.com )

University of Petroleum and Energy Studies

\section{Research Article}

Keywords: National Green Tribunal, access to environmental justice, India, NGT Act, environmental justice

Posted Date: September 13th, 2021

DOl: https://doi.org/10.21203/rs.3.rs-792456/v1

License: (c) This work is licensed under a Creative Commons Attribution 4.0 International License. Read Full License 


\section{Abstract}

Established in 2010, it has been more than a decade since the establishment of the National Green Tribunal in India and in this context, the effectiveness of the National Green Tribunal as an institution comes to the forefront specifically from the lens of access to justice. To fill in the gap that is existing in the environmental area in the social and economic dimension role of an effective institution created for environment protection is a matter of utmost relevance. The judicial mechanism as a means of access to justice in environmental matters as one of the pillars of environmental governance is seen as means for achieving environmental justice and bringing in environmental democracy. National Green Tribunal is a quasi-judicial body dealing specifically with environment-related civil litigations, which brings about the plurality of justice with its multidisciplinary approach. This paper through the analysis of judgments of the year 2019 of the specific months where the tribunal has done significant intervention, through analysis looks into the impact the judgments have concerning environmental protection and innovations brought and jurisprudence created through its judgments and impact on the access to environmental justice.

\section{Introduction}

Specialized environmental courts are the forums for the realization of access to justice in environmental matters. There have been specialized environmental courts existing for a long time like in Australia, New Zealand, Scandinavia, and the U.S.A however, a discussion on the National Green Tribunal of India in the major developing country becomes of utmost importance. Specialized environmental tribunals are one of the most dramatic establishments of the $21^{\text {st }}$ century. In the 1970 s, only a handful number of the environmental court tribunal existed and now over 1200 environmental court tribunal exist at the national regional level in developed, developing countries, and Environmental court tribunals are dramatically changing the way environmental disputes are resolved. (G. Gill, 2017). The National Green Tribunal of India is the pioneer in developing countries as far as the establishment of the specialized tribunal in environmental matters is concerned. It makes a very good study established over a decade ago. The objective behind its establishment was to bring the realization of the right to a healthy environment under Art 21 and bring more Access to Justice in environmental matters. It was established through the National Green Tribunal Act in 2010. The authorizing legislation gives it a broad trial, Appellate jurisdiction overall environmental and natural resources law, review only by the supreme court, flexibility in its procedure, strict standards for judicial appointments, recognition of the right to a healthy environment, some of the broadest principles on this planet for public participation and access to justice and a mandate to apply international treaties and principles.

Access to information, public participation, and access to justice are important elements of environmental democracy. The National Green Tribunal of India established in 2011 is a giant step towards achieving environmental democracy. Tracing the historical background, which led to the creation of this specialized tribunal, is several international conferences and declarations in the international context. The preamble of the National Green Tribunal Act mentions that since India, being party to the 
decisions taken at the United Nations Conference on Human Environment held in Stockholm in June 1972, which called upon the states to take appropriate steps for the protection, and improvement of the environment. Hence, India was under the responsibility to take an appropriate step for the protection of the environment. After this, the amendment to the constitutions was made, and the $42^{\text {nd }}$ amendment(Constitution (Forty-second Amendment) Act, 1976, S. 11 (w.e.f. 3-1-1977)of the constitution led to the insertion of Art 48-A(Constitution (Forty-second Amendment) Act, 1976, S. 11 (w.e.f. 3-11977) which is the Directive Principle Of State Policy, and Art 51(A)(g) Constitution (Forty-second Amendment) Act, 1976, S. 11 (w.e.f. 3-1-1977) which is the Fundamental Duty of the citizen for the protection of the environment. Thereafter through the interpretation of these provisions, the Supreme Court and the High Court developed the broader dimensions of the right to life under Art 21 and interpreted through various decisions the right to the environment as being part of the right to life. However, while deciding the environmental issues the court was facing a major challenge, as the environmental disputes require expert and technical knowledge, which was lacking. Therefore, the Supreme Court in its various decisions repeatedly emphasized the establishment of the specialized tribunal with technical and expert members. In the cases of M.C. Mehta Vs. Union of India (AIR 1987 SC 965), Indian Council for Enviro-Legal Action Vs. Union of India (1996 3 SCC 212) and A.P. Pollution Control Board Vs. Professor M.V. Nayudu (1992 2 SCC 718) the Indian Supreme Court held that as environmental cases frequently involve assessment of scientific data, setting up environmental courts on a regional basis with a legally qualified judge and two experts would help speed the judicial process. The push by the court-led parliament; with the Law Commission coming up with the recommendation of the specialized environmental courts. The Law Commission of India (186th Report 2003) recommended the establishment of environmental courts in India. This recommendation was based on a review of the technical and scientific problems that came before the courts and the inadequacy of judicial knowledge on the scientific and technical aspects of environmental issues. The report also noted that the National Environmental Appellate Authority constituted under NEEAA Act 1997 and National Environmental tribunal constituted under National environmental Tribunal Act 1995 are nonfunctional and are there on paper.(http://lawcommissionofindia.nic.in/reports/186th\% 20report.pdf).

Against this backdrop, the National green tribunal of India was created. One of the major declarations that are the precursor for giving impetus is the Rio declaration specifically principle 10 of the declaration. The Rio declaration saw the participation of various countries and happened in the year 1992 and 178 governments adopted the Rio Declaration at the earth summit. Principle 10 of the Rio declaration recognized the fact the environmental issues are best handled by appropriate access to information, opportunity to participate in the decision-making process, and effective access to judicial and administrative proceedings including redress and remedy for all concerned citizens. After the Rio declaration, some 80 governments enacted laws that provide greater access to information (Pring \& Pring, 2016). The challenge is now the implementation of these laws. Governments have provided access to information with the enactment of these laws and have done little in making the citizens part of the decision-making process or in coming up with new ways to resolve the disputes justly and effectively. In 
this context, the role of specialized environmental courts for providing access to environmental justice comes to the center stage.

\section{Purpose of National Green Tribunal}

The idea behind creating or improving environmental courts is the desire to improve the third pillar of environmental democracy(Pring \& Pring, 2016). The National Green tribunal of India was created for speedy environmental justice in environmental matters. It was established on 18 October 2010 under the National Green Tribunal Act 2010. The preamble to the NGT Act 2010 starts with emphasizing the purpose for which the National Green Tribunal is created.

"An Act to provide for the establishment of a National Green Tribunal for the effective and expeditious disposal of cases relating to environmental protection and conservation of forests and other natural resources including enforcement of any legal right relating to the environment and giving relief and compensation for damages to persons and property and matters connected therewith or incidental thereto."

The tribunal has a dedicated civil jurisdiction in environmental matters, which helps in reducing the burden of the higher courts. The Tribunal is mandated to make and endeavor for disposal of applications or appeals finally within 6 months of the filing of the same. The tribunal has original, appellate and exclusive jurisdiction. The original jurisdiction(S-14 of the NGT Act) covers all the cases; which are substantial questions relating to the environment (including enforcement of any legal right relating to the enforcement) arising out of the implementation of the seven laws The Water (Prevention and Control of Pollution) Act, 1974 [Water Act], The Water (Prevention and Control of Pollution) Cess Act, 1977, The Forest (Conservation) Act, 1980, The Air (Prevention and Control of Pollution) Act, 1981 [Air Act], The Environment (Protection) Act, 1986, The Public Liability Insurance Act, 1991, The Biological Diversity Act, 2002. Victims of environmental damage including accidents occurring while handling hazardous wastes can approach the court to seek relief and compensation (section-15 of the NGT Act). The tribunal can order for restoration of the damaged property and the environment. Any case for relief and compensation has to be brought to the tribunal within five years from the date such cause for such relief and compensation first arose. After that, a grace period of sixty days is given. In the case of appellate jurisdiction(S-16 of the NGT Act), the tribunal hears and decides cases in which regulatory approval or consent granted or rejected by the relevant government agency is being challenged. These approvals relate to the seven aforementioned laws. As far as the exclusive jurisdiction(S-17) of NGT is concerned in cases relating to compensation and relief for environmental damage and those cases, in which the appeals are being filed before the regulatory approvals can be brought only before the tribunal. Such cases cannot be entertained by other courts and in case; they are court need to ask the parties to approach the tribunal for adjudication.

As per the NGT Act, an aggrieved person can file a case before the tribunal-it could be an individual, a company, a firm, an association of person(like NGO) even if it is not registered or incorporated, a trustee, a local authority, a government body(Like the SPCB, etc.). The person need not be directly affected by the 
project or development in question but could be any person who is interested in protecting and preserving the environment. The Principal Bench of the Tribunal is situated in New Delhi, with four Zonal Benches in Bhopal, Kolkata, Pune, and Chennai. The powers of the tribunal are the same as that of civil court including the power to summon any person to examine witnesses receive evidence on affidavits, review its decisions, etc. It can regulate its procedure and is guided by principles of natural justice. The Act requires the tribunal to consider the principle of sustainable development, the precautionary principle, and the polluter pay principle while deciding cases and the no-fault liability principle is to be applied in cases involving an accident. Failure to comply with the orders of the tribunal could lead to a fine or imprisonment of the person responsible or both depending on the fact situation.

Appeal to Supreme Court is made if any of the parties is not happy with the decision of the tribunal and it can be filed before the Supreme Court of India within 90 days from the date of the tribunal's order later if sufficient cause for delay is shown to the Supreme Court. The National Green Tribunal is quasi-judicial and has limited powers. Hence it becomes important to analyze the role of the National Green tribunal as far as access to justice is concerned.

Very few studies have been conducted as to the effectiveness and functioning of the National green tribunal of India as an institution and its role in access to environmental justice. (Vasan, 2021) in his work has done a case study of the case filed by the indigenous communities against the hydel power project in the Himalayan state of Himachal Pradesh and how opposing views are taken by conflicting parties and green narrative is taken by the National Green Tribunal in such cases by balancing the conflicts. (G. N. Gill 2020) while discussing plurality of the environmental justice brought by the National Green tribunal with its multidisciplinary approach created a decade ago. She argues about the internal and external forces affecting the NGT. It analyses the reasons and actions of the principal actors in supporting NGT and the ones who are affected by its growth activities and popularity by the use of transmigration of theory. (G. N. Gill, 2019) has used the reported cases of NGT to analyze the applicability of precautionary principle and the legal certainty and uncertainty and the proof and disproof that it requires in the practical context while applying the precautionary principle in its decision. (G. N. Gill, 2016) discusses the role of technical and expert members in the decision-making process. She argues further that despite uncertainty in science the expert members play a central role rather than the marginal in the decision-making process. Interview access and data have provided in her work better insights into the role of technical and expert members in internal decision-making in NGT. (G. N. Gill, 2014) discusses sec 20 of the Ngt Act, which mandates the application of international principles like sustainable development, the precautionary principle, and the polluter pay principle by NGT. It addresses the application of these principles in the Indian context and shows India's commitment towards the international community for environment protection (Dilay, Diduck, \& Patel, 2020) discusses the effectiveness of the NGT in resolving disputes arising from the Environment Impact assessment and the procedural aspect of environment justice(Chowdhury \& Srivastava, 2018) discusses the National Green Tribunal which is the newest of the tribunal; established after the constitutional amendment procedure provided for their creation, specifically focussing on its 
jurisdiction.(Rengarajan, Dhivya, Purvaja, Ramesh,2018) discusses the background to the creation of the National green tribunals and the effectiveness of NGT as an institution by analyzing the judgments given by NGT in the year 2016. He has tried to identify through his work the broad areas in which environmental disputes come to Ngt like air, water, etc., and what are the areas of greatest conflict. (Patra \& Krishna, 2015) in his work has done an empirical analysis of the judgments from its inception in October 2010 to December 2013. He has done impact analysis and areas of conflict although he is seeing NGT as a positive step towards environmental justice.(Shrotria, 2015) in her work through the analysis of Ngt judgments after four years of its establishment brings out the jurisdiction, powers, and functions of NGT in effecting environment justice. She has also traced the environmental jurisprudence evolved and how the tribunal is playing important role in access to justice in environmental matters..(Ravi Rajan, 2014) in his work has discussed the origin and evolution of environmental justice in India in the early 1970s and 1980. He has discussed how after the Bhopal Gas tragedy the scenario changed. He observes that environmental justice discourse has evolved because of the vibrant civil society and it shows the evolution of institutions in the environmental context in the Indian democracy.(Preston, 2014) in his work in the backdrop to the exponential growth of the environmental courts and tribunals tries to conclude as to the features that have contributed to the success of the tribunals. Drawing upon the multiple jurisdictions and identifying best practices it establishes 12 features. These include (i) status and authority; (ii) independence; (iii) centralized jurisdiction; (iv) knowledge of judges and members; (v) operating as a multi-door courthouse; (vi) access to scientific and technical expertise; (vii) facilitating access to justice; (viii) quick and cheap resolution of disputes; (ix) responsiveness to environmental problems; (x) development of environmental jurisprudence; (xi) underlying ethos and mission and (xii) flexible, innovative and provides value-adding function. (Amirante, 2011) in his work discusses the advantages and disadvantages of the environmental tribunals from a comparative perspective and sees it as an important tool for environmental protection in the Asian Region for sustainable development. (Sharma, 2008) talks about the green courts to be independent of political influence and may be established as a specialist division within the high court as a substitute.

\section{Methodology}

Till now the cases that have come before the NGT in a decade of its establishment from its inception till 30/06/2021 as an institution is 35258 out of which $\mathbf{3 2 9 3 6}$ has been disposed of and2322 is pending before the tribunal.( https://greentribunal.gov.in/).All of them are related to the environment from a broader perspective but there is a need to know specific areas like afforestation, forest clearance, coastal zone, etc, which is brought to the National Green Tribunal as a way of petitions and appeals. Since there is a gap in the literature and limited studies as to the analysis of the judgments after 2015. Hence, the present paper will delve into the question of the role of the National green tribunal and its impact is concerned through the analysis of significant interventions done by the NGT with special emphasis on the cases of the months January, February, and March of the year 2019. Hence, the methodology followed for functional analysis is the assessment of the corpus of the judgments for specific months which were significant interventions done by the National Green tribunal. All the significant interventions 
for the year January, February and March 2019 has been downloaded from the website of the national green tribunal (https://greentribunal.gov.in/). The analysis intends to focus on several key issues. These include the growth and nature of the NGT's caseload over a period after 2015 and the expansion of the caseload of the principal and regional benches. The judgments were analyzed to learn the details of the plaintiffs and the defendants to understand the terms who are the people approaching frequently approaching the National Green tribunal when it comes to access to environmental justice. Based on the judgments the core points related to environmental issues were classified and analyzed as to what are the issues that bring plaintiffs to the NGT? In addition, the analysis of the number of cases that come before the NGt is increasing or decreasing was done from the website of the NGT. Key environmental factors that influence the access to environmental justice are the National Green Tribunal the decisionmakers and the pollution control boards which are influencers.

\section{Results And Discussion}

Based on the analysis of the judgments there has been an increase in the number of the cases of National Green tribunal with the growth of industrialization and development in a developing country like India. The efficiency of the tribunal as an institution analyzing the data of the total cases that have come before the tribunal as a whole and how many have been disposed and how many are pending. As per the data on the NGT website ( https://greentribunal.gov.in/). As on 30/06/2021 Figure 1 created as per data provided on the website gives the picture that the National Green tribunal, as an institution is very efficient with the number of cases that are coming to it and amount of the cases that has been disposed and pendency of the cases, is very low. As per the National Green Tribunal Act, the tribunal is under the mandate to resolve the cases expeditiously and the tribunal was established with the view to bring speedy justice in environmental matters and as per the Act, the tribunal is under the mandate to dispose of the cases within six months. In addition, it can be concluded through the data that the Tribunal has been achieving the objective of the speedy disposal of environmental matters, as the pendency of cases is very low while the disposal rate is very high as an institution and in the Indian context where cases load is very high.

The National Green Tribunal to provide greater access to justice was established with a principal bench at Delhi and the zonal benches which includes western zonal bench at Pune, southern zonal bench at Chennai, eastern zonal bench at Kolkata, Coastal zonal bench at Bhopal, and efficiency-wise as one looks to the data for bench wise performance as far as pendency of cases is concerned.

As per the data taken from the National Green tribunal website and looking to the pendency of the cases, zone-wise (figure 2) brings a clear picture as to how the benches have performed in terms of efficiency since its inception. The maximum number of pendency is at the Pune bench, which is the west zone bench while the minimum number of pendency is at the Bhopal bench, which is the central zone bench while in the case of other benches the pendency is in between the two benches. 
During the analysis of the judgments from 2015-20(figure 3), it was seen the number of cases are on increase including all the benches maximum being in the year 2017 and the lowest being in 2020 (Figure 3 )due to the covid 19 situations as the tribunal was working in the online mode.

Analysis was done for the zone-wise judgments for the year 2019 (figure 4) maximum judgments have been delivered by the principal bench while the minimum number has been delivered by the western zone bench. While examining the significant interventions by the court for the year 2019 specifically in January, February, and March. The jurisdiction of the National Green tribunal is over the various enactments The Water (Prevention and Control of Pollution) Act, 1974 [Water Act], The Water (Prevention and Control of Pollution) Cess Act, 1977, The Forest (Conservation) Act, 1980, The Air (Prevention and Control of Pollution) Act, 1981 [Air Act], The Environment (Protection) Act, 1986, The Public Liability Insurance Act, 1991, The Biological Diversity Act, 2002. Accordingly, the cases fall under various categories as issues relating to air, water, forests, mining operations, municipal solid waste management 2016, industrial operations.

The category of cases adjudicated by the National Green Tribunal in these months is an original application filed by the pollution control boards which are the implementing authorities and seeking for enforcement of conditions imposed on polluters, aggrieved persons concerning environmental issues falling under the purview of enactments falling under the purview of the Act, seeking compensation for pollution, environmental damage, etc. appeals from aggrieved person and NGOs for noncompliance of the project authorities the conditions imposed under the environmental and forest clearance given by the ministry of environment and forest for the development project, non-compliance with the norms, appeals from the industries against the decision of the pollution control board. The issues that have come before the National Green Tribunal for adjudication where the tribunal has done the significant intervention in these months deal with the following issues majorly dealing with Water pollution(effluent plants, common treatment effluent plant, cleaning of river), solid waste management, coal mining, industrial activities, environmental damage, Air pollution(thermal power stations, industry pollution ), groundwater contamination, environmental clearance, Noise pollution, project planning, Forest land, flouting environmental norms, biomedical waste, Air pollution, sand mining, river pollution, noise pollution.

\section{Judgment analysis}

The analysis of various judgments and impact the National Green Tribunal has created by way of resolving the disputes is explicit with the detailed analysis done concerning each of the subject areas where the issues were raised on various categories of the subject matter. For the month of January, issues, and directions given by the tribunal are as follows-Water pollution (Aryavart Foundation Versus Vapi Green Enviro Ltd. \&Ors. (O.A.No. 95/2018) tribunal directing for audit of the central pollution control board and setting up of the committee to identify the remedial measures for the functioning of the board asking to pay compensation to pollution control board not following the norms, compliance of solid waste management rules Compliance of Municipal Solid Waste Management Rules-2016 (O.A. No.606/2018) creating task forces apart from the oversight force consisting of High court judges and to 
create awareness on SWM rules 2016, coal mining, Threat to life arising out of coal mining in south Garo Hills district Versus State of Meghalaya\& Ors (O.A. No. 110(THC)/2012) imposing the penalty of Rs 100 crore on the state and state could be made liable for colluding with the polluters apart from noncompliance, cleaning of river Yamuna Manoj Mishra versus Union of India \&Ors. (O.A. No 6/2012) for the execution of directions based on the expert committee recommendation and to furnish a performance guarantee of Rs 10 crore to ensure compliance, Closure of unauthorized industrial activates in Delhi in residential/non-conforming areas Mayank Manohar \& Paras Singh, Reporter Times of India Versus Govt. of NCT of Delhi \&Ors. (O.A. No. 601/2018) oversight body created headed by the former high court judges, Solid Waste Management in Agra city and areas under the Agra Cantonment Board, and eco-sensitive Taj Trapezium Zone(Social Action for Forest and Environment (SAFE) Versus Union of India \&Ors. (O.A. No. 306/2016) directed state to furnish a performance guarantee of Rs 25 crore to the satisfaction of the Central Pollution Control Board within the timelines in a month, Compliance of Plastic and Solid Waste Management Rules, 2016 at the railway compartments, stations, and railway tracks(Saloni Singh \&Anr. Versus Union of India \&Ors. (O.A. No. 141/2014)directed selected railway stations to achieve environmental standards in form of an environmental management system within 3 months, Environmental damage by marriage halls in Ghaziabad(Sri Om Tyagi Versus Ministry of Environment \& Forest \&Ors (O.A. No.412/2018) Tribunal constituted an oversight committee for Delhi to look compile data of places where marriages and functions take place in Delhi, regulate noise caused by DJ's and crackers, etc., ensure compliance of Solid Waste Management Rules, 2016 among other things., Air pollution by Thermal Power Stations in Districts of Singrauli, Madhya Pradesh and Sonebhadra in Uttar Pradesh(Ashwani Kumar Dubey Versus Union of India \&Ors. (O.A. No. 164/2018) The Tribunal directed the polluting units to take steps within prescribed timelines to furnish Performance Guarantees CPCB to the extent assessed by the oversight committee headed by former high court judge and asked secretaries of state of UP and MP to submit the health status of the people and any disease by which people were affected in two months and long term plan for providing portable water, Pollution caused by drug manufacturing units in Patancheru and Bollaram industrial clusters in Telangana State. Chidambaram Versus Krishna Limited Unit II \&Ors. (Appeal No. 141/2018) (Earlier Appeal No. 123/2013 (SZ), Cleaning of River Periyar Suo Motu proceedings initiated based on the representation received from Justice $R$. Bhaskaran Former Judge Versus State of Kerala \& Ors. (Original Application No. 585/2018) (Earlier O. A. No. 395/2013 (SZ) (THC) The Tribunal constituted a Joint Committee of CPCB, Kerala SPCB, and District Magistrate to forthwith prepare an action plan for compliance of law particularly the biomedical waste and solid waste management Rules and furnish. In these cases, the court has given directions to the government authorities to giving compensation to defaulters and setting up expert committees wherever required, create the oversight committee, furnishing guarantee for performance and payment of damages in cases of environmental degradation.

For February,, the significant interventions by the tribunal have been the Establishment and functioning of Effluent Treatment Plants (ETPs), Common Effluent Treatment Plants (CETPs), and Sewage Treatment Plants (STPs) Paryavaran Suraksha Samiti\& Anr. Versus Union of India \& Ors. (O.A. No.593/2017) where the tribunal has come up with the scientific formula to calculate environment compensation for polluting 
industries which is a significant step in combating pollution, Amendment' to the Environment Clearance (EC) for expansion of real-estate projects Anil Tharthare) Versus The Secretary, Envt. Dept. Govt. of Maharashtra \& Ors. (Appeal No. 122/2018) the tribunal held the office order of amendment of the expansion of construction projects and modifying environmental clearance is invalid and directed the project proponent to deposit 1 crore with CPCB within 1 month, Air pollution in the outskirts of Mumbai due to emissions by oil companies and similar businesses (CharudattKoli Versus M/ s. Sea Lord Containers Ltd.(O.A. No. 40/2014) The Tribunal has noted that the liability of companies including Bharat Petroleum Corporation Limited and Hindustan Petroleum Corporation Limited has been established in failing to comply with the previous directions, The Tribunal has directed the preparation of an integrated action plan to be submitted to CPCB, Pollution of Thirumanimuthar River in Tamil Nadu due to discharge of industrial effluents and municipal sewage(V. Manickam Versus The Secretary, Tamil Nadu Pollution Control Board \& Ors. (O.A. No 51/2015 (SZ)) the Tribunal directed a joint inspection to ascertain present status by a team comprising of representatives of CPCB and Tamil Nadu Pollution Control Board to finalize compensation is required to be recovered from Salem Municipal Corporation as well as from polluting industries. Meanwhile, Salem Municipal Corporation is directed to deposit an interim compensation of Rs. 25 lacs with the CPCB within one month and also furnish a Performance Guarantee of Rs 50 lakhs to CPCB to ensure that untreated effluents will not be discharged and necessary steps to prevent such discharge will be taken positively within three months failing which the amount of Performance Guarantee will be forfeited, Curbing noise pollution as per the statutory mandate of Noise Pollution (Regulation and Control) Rules 2000(Hardeep Singh \& Ors. Applicant(s) Versus SDMC \& Ors. (O.A. No. 519/2016) on failure to comply with the previous directions of the tribunal, the tribunal asked the Delhi government to file a fresh compliance report within a month and deposit rs 5 lakhs as the cost with the CPCB, Contamination of groundwater in Delhi(Tribunal on its motion Versus Govt. of NCT of Delhi \& Ors. (O.A. No.496/2016) the tribunal took into account several steps by the independent monitoring committee appointed by the Delhi Jal Board to curb the contamination and rejuvenation of groundwater and suggested the committee can meet the expert committee set for cleaning river Yamuna, Prevention and remedying pollution in river Mondovi in Goa(Kashinath Shetye \& Ors. Versus Srinet Kotwale \& Ors. (O.A. No. 486/2018 (WZ)) The Tribunal also directed GPCB to make an assessment of the amount of compensation to be recovered and the persons from whom such recovery is to be effected, Pollution of rivers Satluj and Beas in the State of Punjab (Sobha Singh \& Ors. Versus State of Punjab \& Ors. (O.A. No. 916/2018) the Tribunal also appointed new members to the monitoring committee to strengthen its functioning, Measures to protect the trees planted at public places $P$. Edwin Wilson Versus The State of Tamil Nadu \& Ors. .(O.A. No.168/2017(SZ)) After Greater Chennai Corporation submitted that Detailed Project Planning for Sustainable Plantation Strategy Tribunal directed that de-concretizing to the extent of less than one meter around the trees may be completed within three months.

In March, the significant intervention of the tribunal has been in areas like Determination of whether the land in question in Haryana is 'forest' Lt. Col. (Retd.) Sarvadaman Singh Oberoi versus State of Haryana \& Ors. (O.A. No. 407/2017) The Tribunal applied the test laid down by landmark rulings of the Supreme Court that for an area to be defined as forest land by the Forest Department, an ordinary dictionary 
meaning of the word forest is applicable and not whether the area is recorded as forest in the revenue record, Remedial measures to be taken to bring the air quality of 102 cities identified as 'non-attainment cities', which do not meet the National Ambient Air Quality Standards News item published in "The Times of India" Authored by Shri Vishwa Mohan Titled "NCAP with multiple timelines to clean air in 102 cities (O.A. No. 681/2018) it was respect to action submission to CPCB and states who have not submitted were required to pay compensation of Rs 1 crore and states failing to remove deficiencies in action plan liable to pay Rs 25 lac, Violation of environmental norms by M/s Ansal Buildwell Rajendra Kumar Goel versus Ministry of Environment \& Forests \& Ors. (O.A. No. 378/2016) the tribunal was tasked with taking remedial, preventive, and punitive measures for flouting environmental norms Tribunal directed the real estate promoters to deposit a sum of Rs. 10 crores as interim compensation with the CPCB within one month and an interest of $12 \%$ for any delay in depositing the compensation and also prosecution and recovery of damages, Illegal drawl of groundwater Harinder Dhingra Versus International Recreation \& Amusement Ltd.\& Ors (O.A. No. 458/2017) directed a committee with representatives of MoEF\&CC, CPCB, Central Ground Water Authority and District Magistrate, Gurgaon to review the existing policy of permitting the supply of water for commercial purposes, when drinking water is scarce and whether the water is being diverted from the river supply for commercial use, without affecting e-flows, Non - compliance with the provisions of Bio-medical Waste Management Rules, 2016 (BMW Rules) Shailesh Singh Versus Sheela Hospital \& Trauma Centre, Shahjhanpur \& Ors (O.A. No. 710/2017) because of ensuring compliance of BMW Rules in Uttar Pradesh an action plan was to be submitted with CPCB to ensure compliance, the Tribunal directed that states will be liable to pay a compensation of Rs 1 crore a month for delay in filing reports, Remedial steps to be taken for control of air pollution in the outskirts of Mumbai (Charudatt Koli Versus M/s Sea Lord Containers Ltd. (O.A. No. 40/2014) Tribunal had directed the preparation of an integrated action plan to be submitted to CPCB by the public sector refineries. Tribunal directed that the refineries pay interim compensation to the petitioners who have suffered health consequences over and above their medical bills, Monitoring mechanism for compliance of conditions of environment clearance evolved by MoEF\&CC(Sandeep Mittal Versus Ministry of Environment, Forests \& Climate Change \&Ors. (O.A. No. 837/2018) the Tribunal had directed the MoEF \&CC to furnish data and strengthen the mechanism to periodically monitor the compliance of environmental clearance conditions. However, the data furnished is wholly inadequate to evaluate the effectiveness of the functioning of the mechanism and merely mentions figures of the projects monitored, without mentioning the extent of defaults found and further action is taken. Taking note of the omission, the Tribunal directed the official who has furnished the data to remain present in a person with the entire relevant data, improper disposal of the fly ash by the Thermal Power Plants (Sandplast (India) Ltd. \& Anr. Versus Ministry of Environment and Forest \& Ors. (O.A. No. 102/2014), Implementation of orders issued to remedy pollution of River Ganga M.C. Mehta Versus Union of India \& Ors. (O.A. No. 200/2014) Finding incomplete action plans, the Tribunal warned that the National Mission for Clean Ganga and the states of Uttar Pradesh, Bihar, Jharkhand, and West Bengal will have to pay compensation for not responding and failing to formulate the action plans for Phase II and III within a week, Illegal sand mining- particularly where mining leases were granted before obtaining environmental clearance Himmat Singh Shekhawat Versus State of Rajasthan \& Ors. (O.A. No. 671/2017) Tribunal's 2015 decision declaring the notifications granting mining 
leases without a valid environmental clearance invalid, states were required to submit a progress report. The Tribunal noted that Karnataka, Rajasthan, and Madhya Pradesh had also failed to file the reports along with Himachal Pradesh inability to conform to norms due to shortage of staff, remedial measures for the industrial or other pollution in Kali Nadi, Krishna, and Hindon Rivers Doaba Paryavaran Samiti Versus State of U.P. \& Ors (O.A. No.231/2014) Tribunal seized with pollution of rivers Kali, Krishna and Hindon which has resulted in diseases and deaths of inhabitants of the area, had appointed a supervisory committee to effectively monitor the progress. So far, the prosecution has been initiated against 118 non-complying industries in Muzaffarnagar, Shamli, Meerut, Baghpat, Ghaziabad, and Gautam Budh Nagar in Uttar Pradesh. Based on the recommendations, the Tribunal has directed UP to prepare an action plan to ensure the water quality of river Hindon at least meets the water quality criteria for bathing and furnish a performance guarantee of Rs. 5 crores. Significantly, the Tribunal directed that failure to implement the action plan within six months will result in forfeiture of the guarantee, control of noise pollution under the Noise Pollution (Regulation and Control) Rules, 2000 Hardeep Singh \& Ors.

Versus SDMC \& Ors. (O.A. No. 519/2016)

Analyzing the remedies that have been given by the tribunal they fall within in the form of directions to defaulters or by Setting up of committees, joint committees, oversight committees, audit of the pollution board, compensation, creation of task force for compliance, imposing a high penalty on the state as high as up to Rs 1 crore, performance guarantee for the execution of directions, environmental compensation by drawing a scientific formula, compensation payment, joint inspection, monitoring committees, furnish data, action plan. The tribunal has employed such directions thus played an investigative role at times at other time has played a consultative role by consultation with the stakeholders and by setting up of the specialist committee, it has brought in in dialogue between the stakeholders and brought in, a participative approach which can bring contradictory claims and positions. Stakeholder's role has broad impacts in the cases of river cleaning and air pollution. Specialized committees promote a cooperative approach but at the same fix the accountability of the stakeholders who are involved. Thus in this way, the National Green Tribunal has promoted greater access to justice by resolving the disputes with the participative approach by involving the stakeholders. The NGT has a huge amount of pressure as it is under the mandate to resolve the disputes within six months and to bring in speedy justice in environmental matters. However, the way NGT is bringing in democratic ways of resolving disputes is bringing in more environmental democracy and ushering in an era of better access to environmental justice. Over a decade of its establishment with the development and evolving complexity of environmental problems, the NGT has been successful in promoting access to environmental justice by bringing a participative approach to resolving disputes and establishing itself as an efficient tribunal with a very little rate of pendency of disputes.

\section{Declarations}

Ethics approval and consent to participate-NA

Consent for publication-NA

Page $12 / 16$ 
Availability of data and materials-data has been taken from the official website of National Green Tribunal of India ( https://greentribunal.gov.in/).

Competing interests-NA

Funding-NA

Authors' contributions-NA

Acknowledgements-NA

Authors' information (optional)-NA

\section{References}

1. Amirante, D. (2011). Environmental Courts in comparative perspective: preliminary reflections on the National Green Tribunal of India. Pace Envtl. L. Rev., 29(August 2002), 441.

2. Chowdhury, N., \& Srivastava, N. (2018). The National Green Tribunal in India: Examining the question of jurisdiction. Asia Pacific Journal of Environmental Law, 21(2), 190-216. https://doi.org/10.4337/apjel.2018.02.06

3. Dilay, A., Diduck, A. P., \& Patel, K. (2020). Environmental justice in India: a case study of environmental impact assessment, community engagement and public interest litigation. Impact Assessment and Project Appraisal, 38(1). https://doi.org/10.1080/14615517.2019.1611035

4. Gill, G. (2017). Environmental Justice in India. In Routledge Taylor and Francis group. https://doi.org/10.4324/9781315686592

5. Gill, G. N. (2014). The National Green Tribunal of India: A Sustainable Future through the Principles of International Environmental Law. Environmental Law Review, 16(3), 183-202. https://doi.org/10.1350/enlr.2014.16.3.217

6. Gill, G. N. (2016). Environmental Justice in India: The National Green Tribunal and Expert Members. Transnational Environmental Law, 5(1), 175-205. https://doi.org/10.1017/S2047102515000278

7. Gill, G. N. (2019). The precautionary principle, its interpretation and application by the Indian judiciary: 'When I use a word it means just what I choose it to mean-neither more nor less' Humpty Dumpty. Environmental Law Review, 21(4), 292-308. https://doi.org/10.1177/1461452919890283

8. Patra, S. K., \& Krishna, V. V. (2015). National green tribunal and environmental justice in India. Indian Journal of Geo-Marine Sciences, 44(4), 445-453.

9. Preston, B. J. (2014). Characteristics of successful environmental courts and tribunals. Journal of Environmental Law, 26(3), 365-393. https://doi.org/10.1093/jel/equ019

10. Pring, G., \& Pring, C. (2016). Environmental Courts \& Tribunals: A guide for policy makers. In Unep. Retrieved from http://wedocs.unep.org/bitstream/handle/20.500.11822/10001/environmentalcourts-tribunals.pdf? sequence=1\&isAllowed=y 
11. Ravi Rajan, S. (2014). A History of Environmental Justice in India. Environmental Justice, 7(5), 117121. https://doi.org/10.1089/env.2014.7501

12. Rengarajan, S., Palaniyappan, D., Ramachandran, P., \& Ramachandran, R. (2018). National Green Tribunal of India-an observation from environmental judgments. Environmental Science and Pollution Research, 25(12), 11313-11318. https://doi.org/10.1007/s11356-018-1763-2

13. Sharma, R. (2008). Green Courts in India Strengthening Environmental Governance - Student Note. Law, Environment and Development Journal, 4(1), 50-71.

14. Shrotria, S. (2015). Environmental justice: Is the National Green Tribunal of India effective? Environmental Law Review, 17(3), 169-188. https://doi.org/10.1177/1461452915595548

15. Vasan, S. (2021). We Are All Environmentalists! Framing Life in the National Green Tribunal, India. Journal of Developing Societies, 37(2), 151-166. https://doi.org/10.1177/0169796X211001229

\section{Figures}

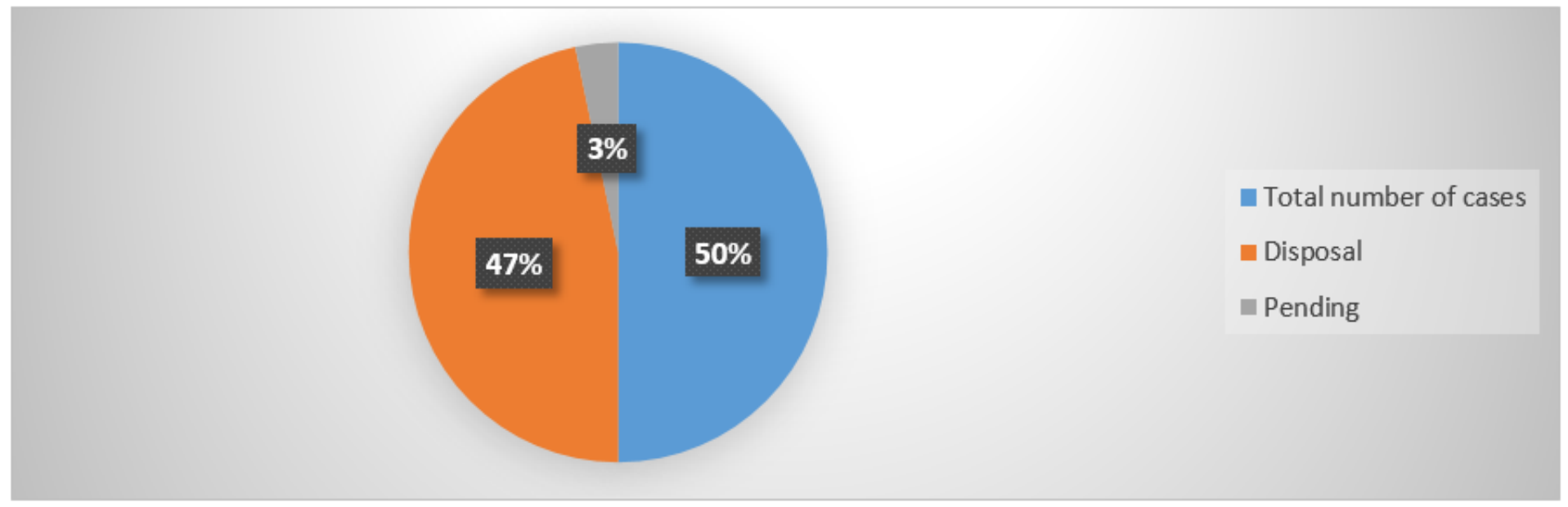

\section{Figure 1}

Total of the institution, disposal, and pendency of the cases of NGT principal bench and all zonal benches from the date of its inception till 30.06.2021 


\section{Chart Title}

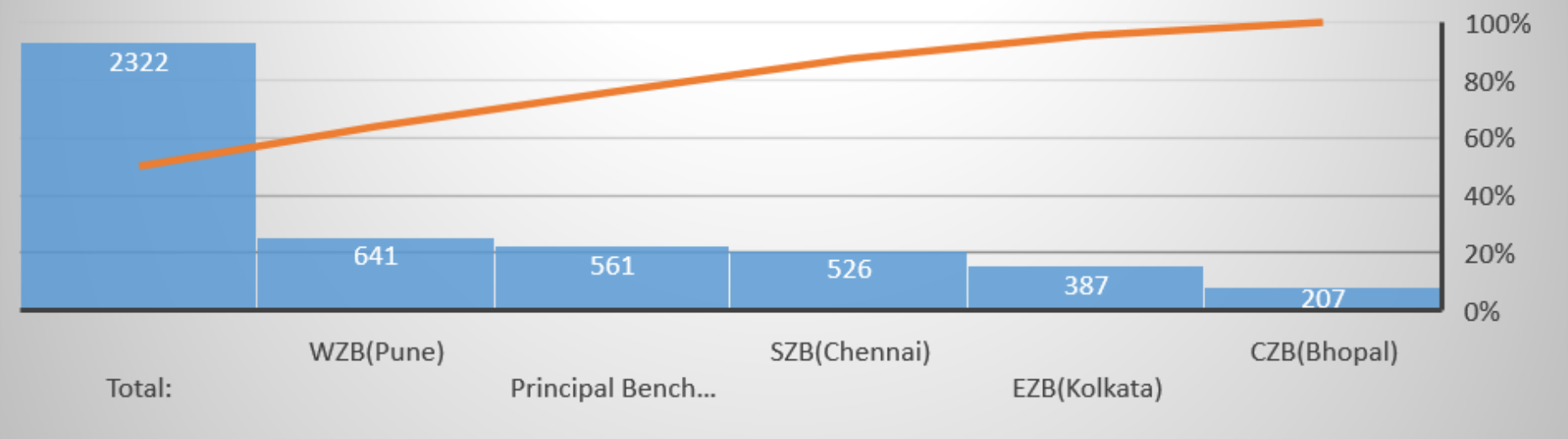

Figure 2

Zone Wise Pendency as on 30/06/2021

\section{No. of cases handled}

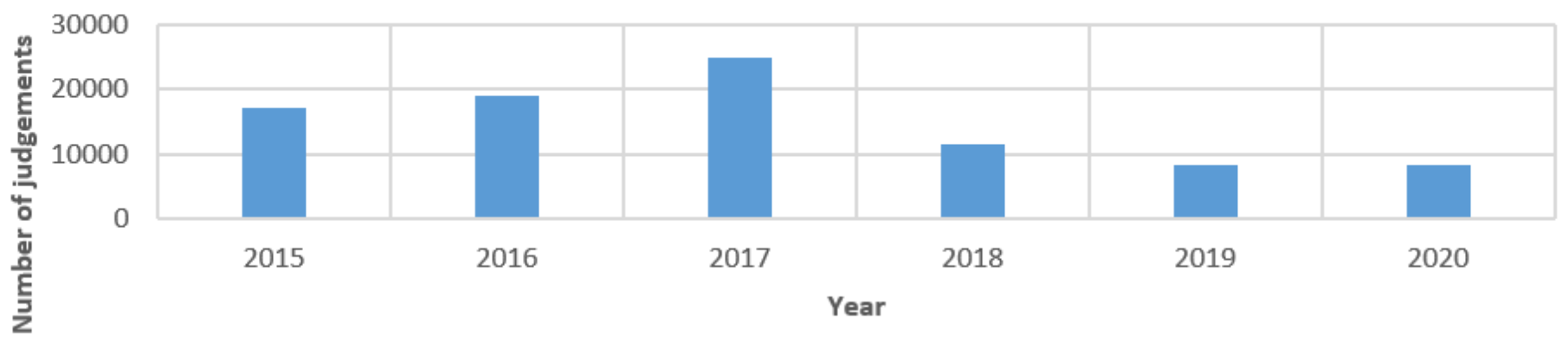

\section{Figure 3}

Environmental judgments delivered by the NGT from 2015-20 


\section{zonewise judegments 2019}

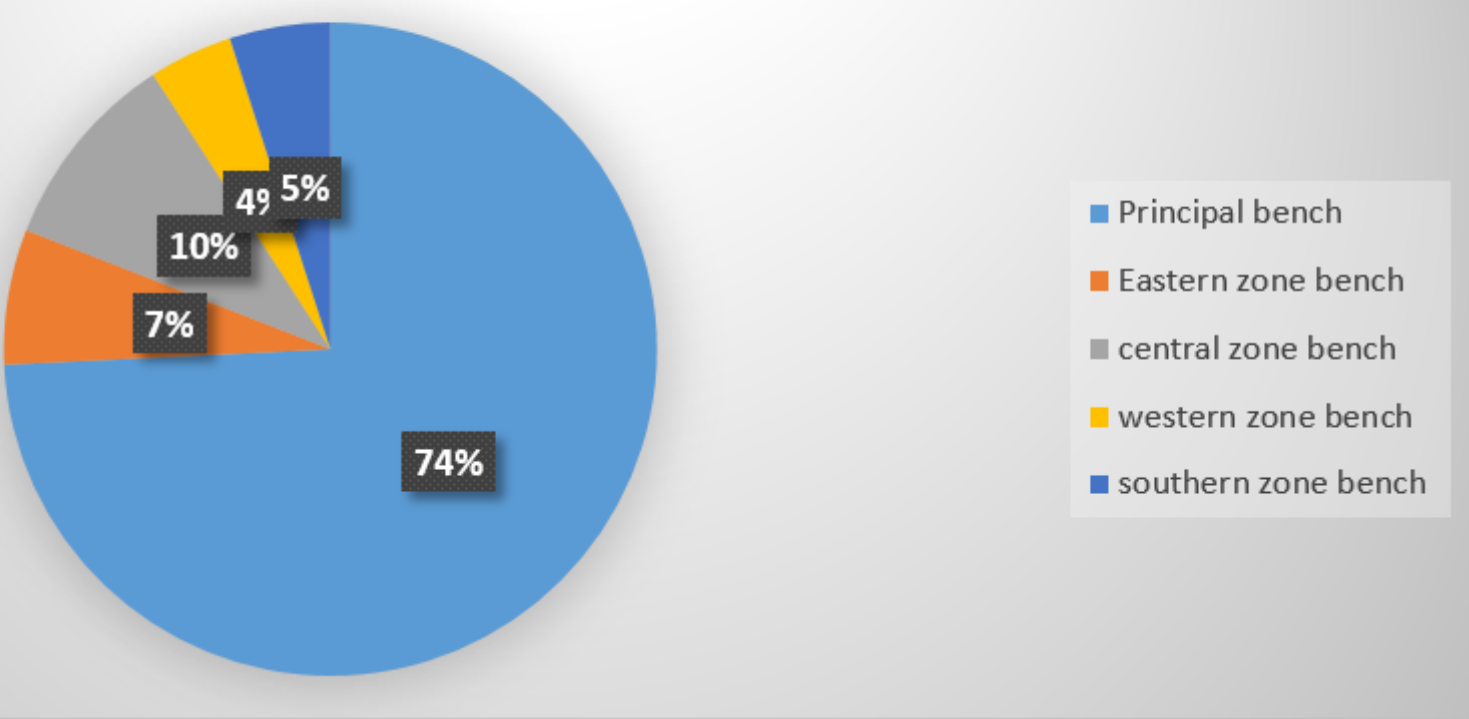

Figure 4

Zone Wise Judgments for the year 2019 